\title{
The Role of Hygiene and Sanitation to the Escherichia coli Contamination in Drinking Water in Depok City, Indonesia
}

\author{
Bambang Wispriyono*(D), Lia Arsyina, Iqbal Ardiansyah, Laura D. Pratiwi(D), Ririn Arminsih(D), Budi Hartono,
} Nurmalasari Nurmalasari, Randy Novirsa

Department of Environmental Health, Faculty of Public Health, Universitas Indonesia, West Java, Indonesia

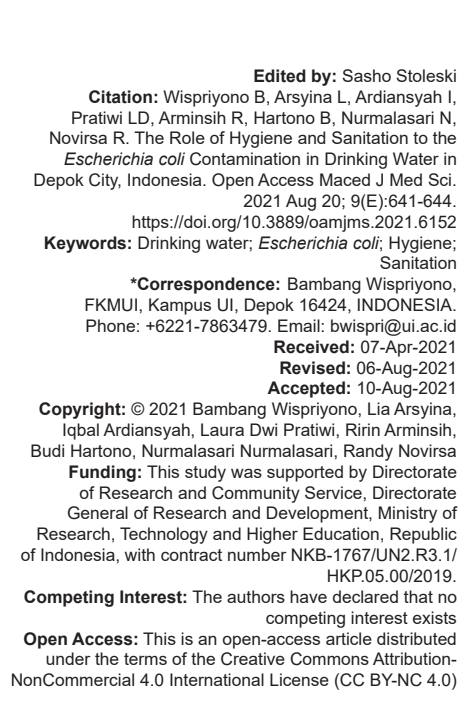

Abstract

BACKGROUND: Drinking water is a vital aspect in human life. The quality of drinking water should be monitored to ensure public from any health effects caused by contaminated water. Escherichia coli (E. coli) is one of the indicators of fecal contamination should not be present in drinking water $(0 \mathrm{cfu} / 100 \mathrm{ml})$. However, poor hygiene and sanitation contributes to $E$. coli contamination in drinking water, particularly in developing countries.

AIM: We investigated the household hygiene and sanitation factors and the relationship with $E$. coli detection in the household drinking water.

METHODS: A cross-sectional study design was conducted to collect the data from three districts in the Depok city, that is, Sawangan, Bojongsari, and Cipayung. A total of 300 houses and the corresponding drinking water samples were collected during August-September 2019. E. coli was determined as microbiological indicator using total plate count method.

RESULTS: The results showed that $E$. coli was detected in $174(58 \%)$ of household water samples. The wate container condition $(\mathrm{OR}=2,60 ; \mathrm{Cl} 95 \%: 1.18-5.71)$ and the hand washing practice with soap $(\mathrm{OR}=1,65 ; \mathrm{Cl} 95 \%$ : 1.04-2.62) were significantly correlated with the presence of $E$. coli in the water samples.

CONCLUSIONS: The condition of the water container was the most dominant factors which contributed to $E$. coli content in the household drinking water.

\section{Introduction}

The water quality, especially drinking water, can directly affect human health. The importance of maintaining the water quality has been globally recognized as one of the goals of the United Nations' (UN) Sustainable Development Goals (SDGs) (number 6 ) which related to the clean water and sanitation aspect. The goal is to achieve $100 \%$ proper, safe, and affordable drinking water available for all people [1].

The quality of drinking water is determined by its physical, biological, and chemical indicators. The biological indicators, especially the presence of Escherichia coli (E. coli) bacteria, are considered as the essential criteria of drinking water quality. E. coli is commonly found in the lower intestine of humans and animals. The presence of $E$. coli in drinking water can be affected by several factors, one of them is the poor sanitation hygiene condition, for example, fecal disposal facility, clean water facility, and the hand washing practice with soap [2].
To date, the UN and the World Health Organization (WHO) estimated that there are more than 844 million people in the world who has limited access to safe drinking water. Globally, 2.3 billion people are living without any access to proper sanitation. Besides that, there are around 892 million people around the world without a proper way to dispose a fecal matter [3]. The lack of clean water and sanitation hygiene contributed to 600,000 children's death caused by diarrhea [3]. Furthermore, $70 \%$ of children are sick with diarrhea which caused by the contamination of water container during the rainy season [4].

The Depok city has been stated as an open defecation non-free. This condition may have been contributed to the risk of $E$. coli contamination in the water sources. Meanwhile, diarrhea is the third major cause of children death in Depok city [5].

Up to our knowledge, this is the first study in Depok city investigating the relationship between personal sanitation and hygiene with the household drinking water quality. We expect that the results of this study can contribute to new insight and valuable 
data to support policy-making on drinking water quality in Depok city. Besides that, the information gathered in this study will help to determine the proper effort to achieve the goals of the SDG in the year 2030 .

\section{Materials and Methods}

This study was conducted using a crosssectional design in three districts of Depok city, that is, Sawangan, Bojongsari, and Cipayung (Figure 1). Questionnaire data and water samples were collected from August 2019 to September 2019 with a total of 300 households samples from 15 subdistricts. Household samples were selected randomly. The personal hygiene and sanitation data were collected through interviews and observations with the questionnaires. The water samples were collected using clean cup at around $200 \mathrm{ml}$ and stored in sterilized PP bottle container in each household (a total of 300 samples). Water samples were then kept in refrigerator under $4^{\circ} \mathrm{C}$ before analysis. The sampling procedure in this study was done with clean practice to prevent any cross-contamination from the tools and the officer. $E$. coli in drinking water was determined using the total plate count method [2]. This study has been approved by the ethics committee in fulfilling research protocols. Ethical clearance was obtained from the Universitas Indonesia [1].
Table 1: The presence of $E$. coli in the household drinking water from the three districts of Depok city

\begin{tabular}{|c|c|c|c|c|c|c|}
\hline \multirow{3}{*}{ The presence of E. coli in the drinking water } & \multicolumn{6}{|c|}{ District name } \\
\hline & \multicolumn{2}{|c|}{ Sawangan } & \multicolumn{2}{|c|}{ Bojongsari } & \multicolumn{2}{|c|}{ Cipayung } \\
\hline & $n$ & $\%$ & $n$ & $\%$ & $n$ & $\%$ \\
\hline $\begin{array}{l}\text { Positive } \\
\text { nat }\end{array}$ & 50 & 62.5 & 71 & 64.5 & 53 & 48.2 \\
\hline Negative & 30 & 37.5 & 39 & 35.5 & 57 & 51.8 \\
\hline
\end{tabular}

\section{Results and Discussion}

\section{E. coli content in the household drinking}

water

E. coli detection in drinking water was found higher in Sawangan (62.5\%) and Bojongsari (64.5\%) and lower in the district of Cipayung (48.2\%) (Table 1).

Based on the rules and regulations established by the $\mathrm{WHO}$, proper drinking water should not contain any $E$. coli. However, in this study, we found that there were $174(58 \%)$ of water samples that did not meet this criterion and contained $E$. coli with a mean value of $35 \mathrm{cfu} / 100 \mathrm{~mL}$. Several studies reported a similar result, for instance, $E$. coli was also found in the drinking water refills (i.e. drinking water treated by local vendors) in the city of Kupang and Sleman, Indonesia [6], [7]. There were also E. coli found in $37 \%$ of bottled water (i.e. drinking water treated by a legitimate company) samples in Sierra Leone [8].

The presence of $E$. coli in drinking water can be caused by many factors including environmental contamination of the water source such as river and flood, and cross-contamination from human with improper hygiene and sanitation during water handling [9].

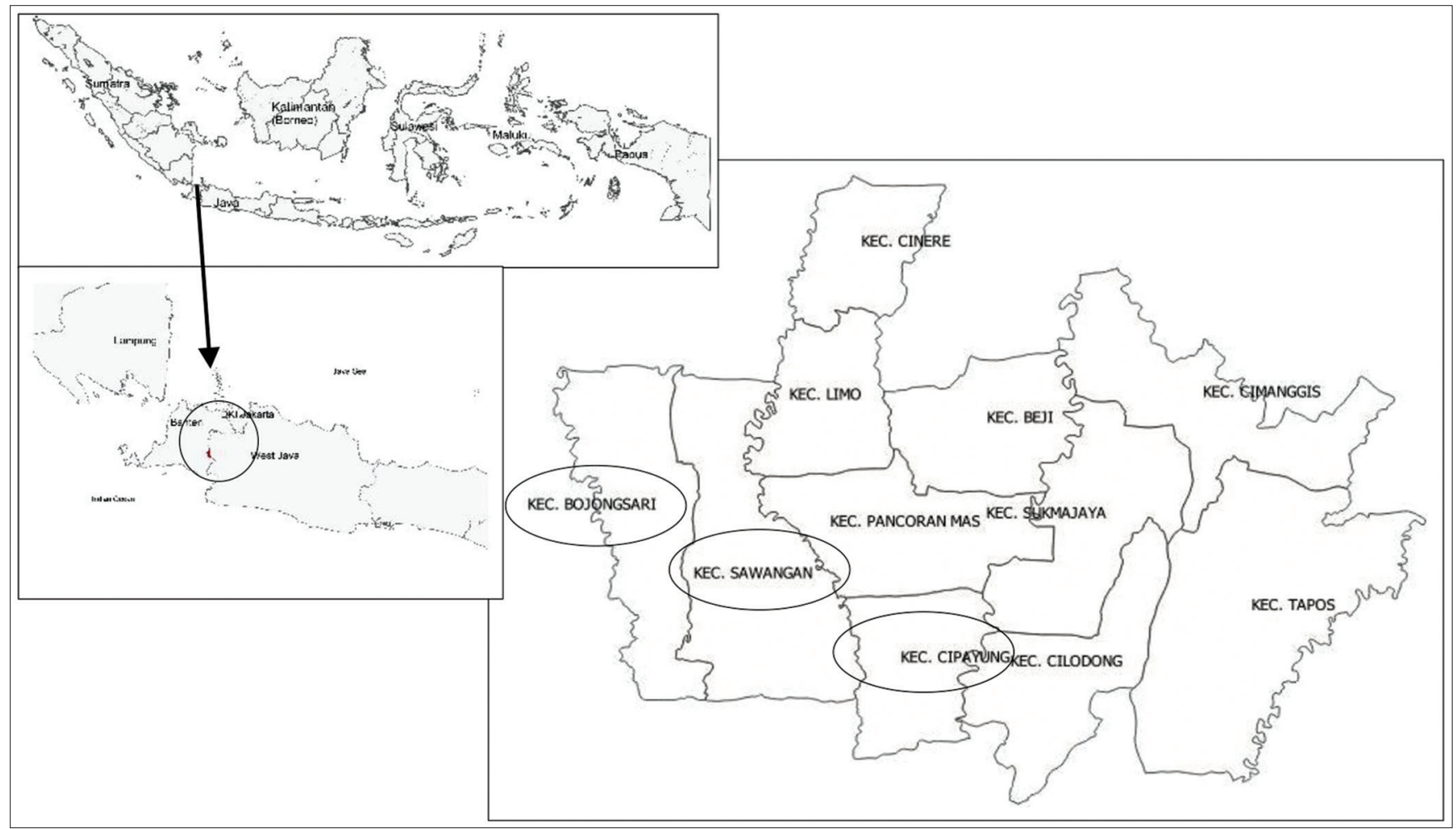

Figure 1: The map of the study location. The three studied districts were marked with circles 


\section{The description of the household sanitation hygiene}

The percentage of the household sanitation hygiene factors, that is, fecal disposal facility, clean water source, condition of the clean water source, drinking water container, and hand washing practice with soap is presented in Table 2.

Table 2: The household sanitation hygiene factors of the three districts in Depok city

\begin{tabular}{|c|c|c|}
\hline Variable(s) & Frequency $(\mathrm{n})$ & Percentage \\
\hline \multicolumn{3}{|l|}{ Fecal disposal facility } \\
\hline Unimproved & 11 & 3.7 \\
\hline Improved & 289 & 96.3 \\
\hline \multicolumn{3}{|l|}{ Clean water source } \\
\hline Unimproved & 229 & 76.3 \\
\hline Improved & 71 & 23.7 \\
\hline \multicolumn{3}{|c|}{ Clean water source condition } \\
\hline Unprotected & 15 & 5.0 \\
\hline Protected & 285 & 95.0 \\
\hline \multicolumn{3}{|l|}{ Drinking water container } \\
\hline Without lid/not clean & 38 & 12.7 \\
\hline With lid and clean & 262 & 87.3 \\
\hline \multicolumn{3}{|c|}{ Hand washing practice with soap } \\
\hline No & 143 & 47.7 \\
\hline Yes & 157 & 52.3 \\
\hline
\end{tabular}

The results showed that hygiene and sanitation facility have achieved proper condition for fecal disposal facility (96.3\%), condition of the clean water source (95\%), drinking water container $(87.3 \%)$, and hand washing practice with soap (52.3\%). However, clean water source was still very low at $23.7 \%$ of the total samples. Our investigation found that almost all of household has a properly structured and protected dug or drilled well for their clean water source needs. However, most of these wells were not able to provide the households with clean water due to its close proximity $(<10 \mathrm{ml})$ to the septic tank in other study, E. coli was detected in 30 different water sources ranging from $<30$ to $4.35 \times 107 \mathrm{cfu} / 100 \mathrm{ml}$. The contamination was caused by fecal contamination from drinking water source with inadequate protection and latrine proximity to sources of water [4]. This condition may directly contribute to the contamination of $E$. coli to the water source. Most of household also has a proper drinking water container, that is, equipped with a lid and clean. The hygiene habit of washing hands with soap has also been done by most of the household.

\section{The relation between hygiene and sanitation with E. coli content in the household drinking water}

The result on the relation between $E$. coli content in the household drinking water with several sanitation hygiene factors is presented in Table 3.

Our statistical analysis found that the clean water source condition was not significantly correlated with $E$. coli content, but had a high-risk factor $(\mathrm{OR}>1)$. Another study in Uganda showed similar results that all water samples from unprotected sources were contaminated with E. coli [10]. It was found that $43 \%$ of water samples from unprotected well in Uganda contained $E$. coli more than $100 \mathrm{MPN} / 100 \mathrm{ml}$ [11].
Table 3: The relation of sanitation hygiene factors with $E$. coli content in the household drinking water

\begin{tabular}{|c|c|c|c|c|c|c|c|c|}
\hline \multirow[t]{3}{*}{ Variable(s) } & \multicolumn{4}{|c|}{$\begin{array}{l}\text { E. coli content in the } \\
\text { drinking water }\end{array}$} & \multirow{2}{*}{\multicolumn{2}{|c|}{ Total }} & \multirow[t]{3}{*}{ OR (Cl 95\%) } & \multirow[t]{3}{*}{ p-value } \\
\hline & \multicolumn{2}{|c|}{ TMS } & \multicolumn{2}{|l|}{ MS } & & & & \\
\hline & $\mathrm{n}$ & $\%$ & $\mathrm{n}$ & $\%$ & $\mathrm{n}$ & $\%$ & & \\
\hline \multicolumn{9}{|l|}{ Fecal disposal facility } \\
\hline Unimproved & 4 & 36.4 & 7 & 63.6 & 11 & 100 & \multirow[t]{2}{*}{$0.40(0.12-1.39)$} & \multirow[t]{2}{*}{0.212} \\
\hline Improved & 170 & 58.8 & 119 & 41.2 & 289 & 100 & & \\
\hline \multicolumn{9}{|l|}{ Clean water source } \\
\hline Unimproved & 132 & 57.6 & 97 & 42.4 & 229 & 100 & \multirow[t]{2}{*}{$0.94(0.55-1.61)$} & \multirow[t]{2}{*}{0.930} \\
\hline Improved & 42 & 59.2 & 29 & 40.8 & 71 & 100 & & \\
\hline \multicolumn{9}{|l|}{$\begin{array}{l}\text { Clean water source } \\
\text { condition }\end{array}$} \\
\hline Unprotected & 11 & 73.3 & 4 & 26.7 & 15 & 100 & \multirow[t]{2}{*}{$2.06(0.64-6.62)$} & \multirow[t]{2}{*}{0.334} \\
\hline Protected & 163 & 57.2 & 122 & 42.8 & 285 & 100 & & \\
\hline \multicolumn{9}{|l|}{ Drinking water container } \\
\hline Without lid/not clean & 29 & 76.3 & 9 & 23.7 & 38 & 100 & \multirow[t]{3}{*}{$2.60(1.18-5.71)$} & \multirow[t]{3}{*}{$0.023^{*}$} \\
\hline With lid and clean & 145 & 55.3 & 117 & 44.7 & 262 & 100 & & \\
\hline $\begin{array}{l}\text { Hand washing practice } \\
\text { with soap }\end{array}$ & & & & & & & & \\
\hline No & 92 & 64.3 & 51 & 35.7 & 143 & 100 & $1.65(1.04-2.62)$ & $0.045^{*}$ \\
\hline Yes & 82 & 52.2 & 75 & 47.8 & 157 & 100 & & \\
\hline
\end{tabular}

In this study, we found that there were two variables that significantly correlated with $E$. coli content in the drinking water, that is, the drinking water container and the hand washing practice with a soap. Other studies also showed the importance of having a proper drinking water container, that is, clean and covered with a lid. A study in Laos and Thailand showed that a lidless drinking water container increased the risk of E. coli contamination [12]. A properly covered container with small openings has successfully decreased $E$. coli contamination in drinking water [13].

The hand washing practice with soap also showed a significant correlation with $E$. coli content in drinking water in several studies. A study in Uganda showed that lack of hand washing practice after toilet use was correlated with the coliform bacterial contamination in drinking water [14]. It was also suggested that washing hands before and after doing activities can reduce the incidence of diarrhea, meanwhile, pet ownership also increases $E$. coli contamination in the soil and correlated with contamination of hands before washing [9]. Human hands act as a media where $E$. coli can be transferred and contaminated the drinking water. A study in India showing that there was a correlation between $E$. coli in hands of household mothers and the presence of $E$. coli in the drinking water [10]. Indeed, washing hands with soap proved to reduce the amount of $E$. coli in the hands effectively and the effect increased as the increase of washing duration [15], [16].

Our multivariate analysis showed that the most dominant factor influencing $E$. coli content in drinking water was the water container condition. This was probably caused by the existing contamination in the water container before refilling the drinking water. Other study showed similar results that the water container was a significant factor influencing the water quality [17]. Even though the drinking water was obtained from an improved water source, the quality will be determined by the storage since contamination mostly happened when using an unsafe and improper container. The 
previous studies have shown that storage with metal containers/pots/vessels was the safest choice to keep the drinking water. Metal container could control E. coli contamination and reduction of tested organism within 0-5 h of holding time [18], [19], [20].

\section{Conclusions}

Almost all of household drinking water samples were contaminated with $E$. coli. the condition of the drinking water container and the hand washing practice with a soap showed significant correlation with the presence of $E$. coli in the drinking water samples. The most dominant sanitation hygiene factors contributed to $E$. coli content in the household drinking water was the condition of the water container.

\section{References}

1. UNDP. Report of the Inter-agency and Expert Group on Sustainable Development Goal Indicators. United Nation Annex IV; 2016. Available from: https://www.sustainabledevelopment. un.org/content/documents/118030fficial-List-of-ProposedSDG-Indicators.pdf. [Last accessed on 2019 Feb].

2. World Health Organization. Gidelines for Drinking Water Quality. Geneva: World Health Organization; 2017.

3. World Health Organization, UNICEF. Progress on Drinking Water, Sanitation and Hygiene Update and SDG Baselines. Geneva: World Health Organization, UNICEF; 2017.

4. Gwimbi P, George M, Ramphalile M. Bacterial contamination of drinking water sources in rural villages of Mohale Basin, Lesotho: Exposures through neighbourhood sanitation and hygiene practices. Environ Health Prev Med. 2019;24(1):33. https://doi.org/10.1186/s12199-019-0790-z

PMid:31092211

5. Dinas Kesehatan Kota Depok. Profil Kesehatan Kota Depok Tahun 2018. Indonesia: Dinas Kesehatan Kota Depok; 2018. https://doi.org/10.22236/arkesmas.v4i2.3750

6. Pakpahan RS, Picauly I, Mahayasa IN. Cemaran mikroba escherichia coli dan total bakteri koliform pada air minum isi ulang. Kesmas J Kesehatan Masyarakat Nasional. 2015;9(4):733. https://doi.org/10.21109/kesmas.v9i4.733

7. Wati NS, Subagiyono S, Wulandari H. Analisis kandungan bakteri total coliform dalam air bersih dan escherichia coli dalam air minum pada depot air minum isi ulang di wilayah kerja puskesmas kalasan sleman. KESMA J Fakultas Kesehatan Masyarakat Univ Ahmad Daulan. 2016;10(2):1-12. https://doi. org/10.25077/jka.v4i2.257

8. Fisher MB, Williams AR, Jalloh MF, Saquee G, Bain RE, Bartram JK. Microbiological and chemical quality of packaged sachet water and household stored drinking water in freetown, Sierra Leone. PLoS One. 2015;10(7):1-17. https://doi. org/10.1371/journal.pone. 0131772

PMid:26162082

9. Navab-Daneshmand $\mathrm{T}$, Friedrich $\mathrm{MN}$, Gächter $\mathrm{M}$ Montealegre MC, Mlambo LS, Nhiwatiwa T, et al. Escherichia coli contamination across multiple environmental compartments (soil, hands, drinking water, and handwashing water) in urban harare: Correlations and risk factors. Am J Trop Med Hyg. 2018;98(3):803-13. https://doi.org/10.4269/ajtmh.17-0521 PMid:29363444

10. Murphy JL, Kahler AM, Nansubuga I, Nanyunja EM, Kaplan B, Jothikumar $\mathrm{N}$, et al. Environmental survey of drinking water sources in Kampala, Uganda, during a typhoid fever outbreak. Appl Environ Microbiol. 2017;83(23):e01706-17. https://doi. org/10.1128/aem.01706-17

PMid:28970225

11. Apecu RO, Ampaire L, Mulogo EM, Bagenda FN, Traore A Potgieter N. Quality of water sources in southwestern uganda using the compartment bag test (CBT): A cross-sectional descriptive study. J Water Sanit Hyg Dev. 2019;9(4):1-11. https://doi.org/10.2166/washdev.2019.270

12. Vannavong $\mathrm{N}$, Overgaard HJ, Chareonviriyaphap T, Dada N, Rangsin R, Sibounhom A, et al. Assessing factors of E. Coli contamination of household drinking water in suburban and rural laos and Thailand. Water Sci Technol. 2017;18(3):886-900. https://doi.org/10.2166/ws.2017.133

13. Ercumen A, Naser AM, Unicomb L, Arnold BF, Colford JM Luby SP. Effects of source-versus household contamination of tubewell water on child diarrhea in rural Bangladesh: A randomized controlled trial. PLoS One. 2015;10(3):1-22. https://doi.org/10.1371/journal.pone.0121907 PMid:25816342

14. Agensi A, Tibyangye J, Tamale A, Agwu E, Amongi C. Contamination potentials of household water handling and storage practices in Kirundo subcounty, Kisoro district, Uganda. J Environ Public Health. 2019;2019:7932193. https://doi. org/10.1155/2019/7932193

15. Kampf G, Kramer A. Epidemiologic background of hand hygiene and evaluation of the most important agents for scrubs and rubs. Clin Microbiol Rev. 2004;17(4):863-93. https://doi.org/10.1128/ cmr.17.4.863-893.2004

PMid:15489352

16. Burton M, Cobb E, Donachie P, Judah G, Curtis V, Schmidt WP The effect of handwashing with water or soap on bacterial contamination of hands. Int $\mathrm{J}$ Environ Res Public Health. 2011;8(1):97-104. https://doi.org/10.3390/ijerph8010097 PMid:21318017

17. Shaheed A, Orgill J, Montgomery MA, Jeuland A, Brown J. Why "Improved" water sources are not always safe. Bull World Health Organ. 2014;92(4):283-9. https://doi.org/10.2471/blt.13.119594 PMid:24700996

18. Packiyam R, Kananan S, Pachaiyappan S, Narayanan U. Effect of storage containers on coliforms in household drinking water. Int J Curr Microbiol Appl Sci. 2016;5:461-77. https://doi. org/10.20546/ijcmas.2016.501.047

19. Kundu A, Smith WA, Harvey D, Wuertz S. Drinking water safety: Role of hand hygiene, sanitation facility, and water system in semi-Urban areas of India. Am J Trop Med Hyg. 2018;99(4):889-98. https://doi.org/10.4269/ajtmh.16-0819 PMid:30062991

20. CDC. Diarrhea: Common Illness, Global Killer. United States: CDC; 2015. 